\title{
New marker of B lymphocytes, MB2: comparison with other lymphocyte subset markers active in conventionally processed tissue sections
}

\author{
P A HALL, ${ }^{*} \dagger$ A J D’ARDENNE, $\dagger$ M G BUTLER, $\dagger$ J R HABESHAW,* \\ A G STANSFELD*†

\begin{abstract}
From the *Imperial Cancer Research Fund, Department of Medical Oncology, the †Department of Histopathology, St Bartholomew's Hospital, London
\end{abstract}

SUMMARY The use of the murine monoclonal antibody MB2 for identifying B lymphocytes in routinely processed tissue was evaluated and contrasted with the use of the monoclonal antibody UCHLl for identifying T cells. One hundred and sixty eight surgical biopsy specimens were immunostained with these antibodies, including a wide range of normal and neoplastic non-lymphoid tissues, as well as normal lymphoreticular tissues and lymphomas. Sixty four non-Hodgkin's lymphomas were also examined, of which 51 had been previously phenotypically defined. In selected cases the results were compared with those obtained using two other monoclonal antibodies MB1 and MT1, used for identifying B and T cells, respectively, in paraffin sections. MB1 stained a smaller proportion of B cell tumours than MB2 and staining was, in general, weaker, except in one case of centroblastic lymphoma. MT1 immunoreactivity was comparable with that of UCHL1, except in one case of T lymphoblastic lymphoma (MT1 positive, UCHL1 negative). None of the antibodies is ideal, but, if used as a panel, they permit the separation of $\mathrm{B}$ cells and $\mathrm{T}$ cells in paraffin sections.

The use of monoclonal antibodies has greatly enhanced the understanding of lymphoreticular disorders, but until recently cryostat sections have been required as most lymphoid antigens have not survived conventional fixation and processing. ${ }^{1-3}$ This imposes a serious limitation on the study of lymphoid disease as most routine histological tissue arrives at the laboratory in fixative. Moreover, the handling of fresh material may put laboratory staff at risk of infection; the tissue requires careful freezing and storage and the morphology of cryostat sections is inferior to that of paraffin sections. The use of the immunogold-silver method, ${ }^{4}$ periodate-lysineparaformaldehyde fixation with low temperature embedding, ${ }^{56}$ and freeze drying techniques ${ }^{7}$ have been advocated to circumvent the requirement for cryostat sections, but these methods are unlikely to be suitable for most routine laboratories.

Several antibodies have been described recently that identify lymphoid cells, ${ }^{8}$ their major subsets, ${ }^{9-13}$ and related antigens ${ }^{1014}$ in conventionally fixed and processed tissue sections. We investigated a further new murine monoclonal antibody (MB2) that recog-

Accepted for publication 14 October 1986 nises a cytoplasmic antigen in reactive and neoplastic B lymphocytes and contrasted its staining with that of a T lymphocyte marker, UCHL1. ${ }^{11}$ In selected cases we compared the characteristics of MB2 and UCHL1 with those of the previously described reagents MB1 and MT1. ${ }^{12} 13$

\section{Material and methods}

MB2 is a murine monoclonal antibody of IgG1 subclass produced by Dr S Poppema (available from BioNuclear Services Ltd and EuroDiagnostic Ltd), which recognises a neuraminidase resistant $28 \mathrm{kD}$ antigen, strongly expressed on B cells and weakly on T cells (S Poppema, personal communication). MB1 and MT1 (BioNuclear Services Ltd) are murine monoclonal antibodies that react with 200,110 , $100 \mathrm{kD}$, and 100 and $110 \mathrm{kD}$ antigens on $B$ and $T$ cells, respectively. UCHL1 is an IgG2a murine monoclonal antibody (supplied by Dr PCL Beverley), which recognises an antigen of $180-185 \mathrm{kD}$ present on a subpopulation of $\mathrm{T}$ cells. ${ }^{15}$

Unbuffered, formal saline, paraffin embedded blocks from normal $(n=19)$ and neoplastic $(n=77)$ lymphoreticular tissues and other normal $(n=36)$ 


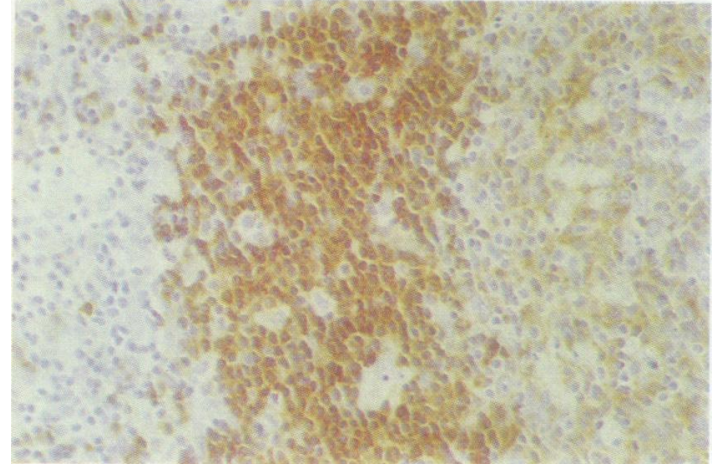

Fig 1 Strong MB2 immunostaining of mantle zone and weak staining of germinal centre cells (left).

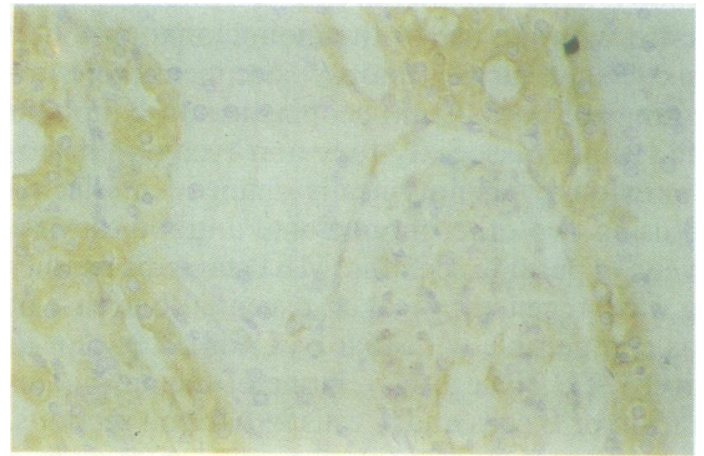

Fig 2a

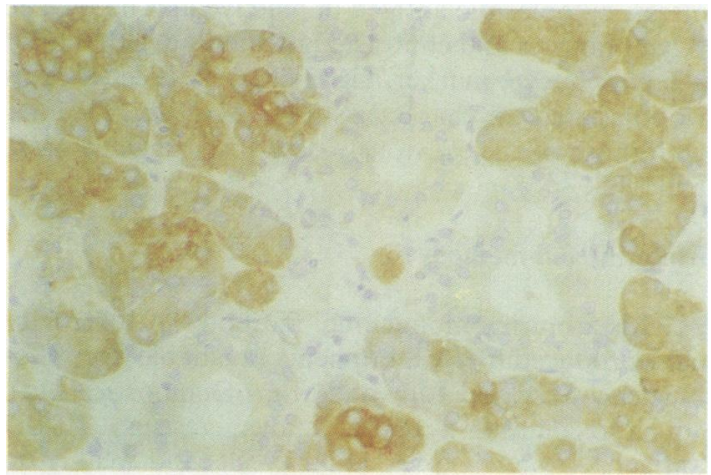

Fig $2 b$

Fig 2a Strong MB2 immunostaining is present in serous cells but is absent from mucous cells of salivary gland. Ducts are weakly stained.

Fig 2b In renal cortex $M B 2$ immunoreactivity is present in distal but not proximal tubules, and granular staining is present in glomeruli.

and neoplastic $(n=36)$ tissues were retrieved from the files of St Bartholomew's Hospital and $4 \mu \mathrm{m} \mathrm{sec}-$

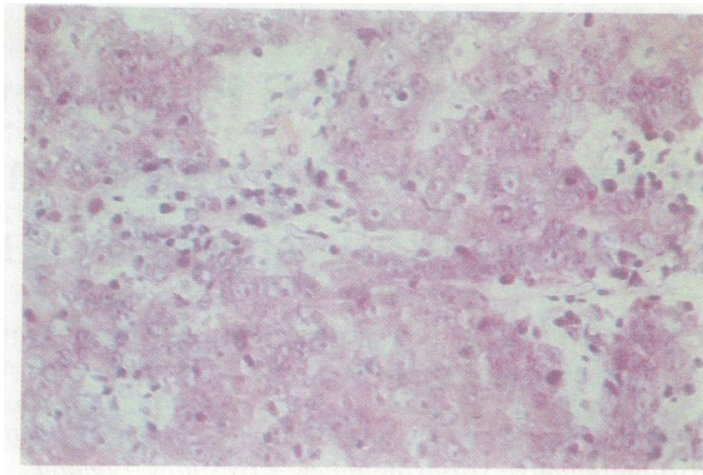

Fig 3a
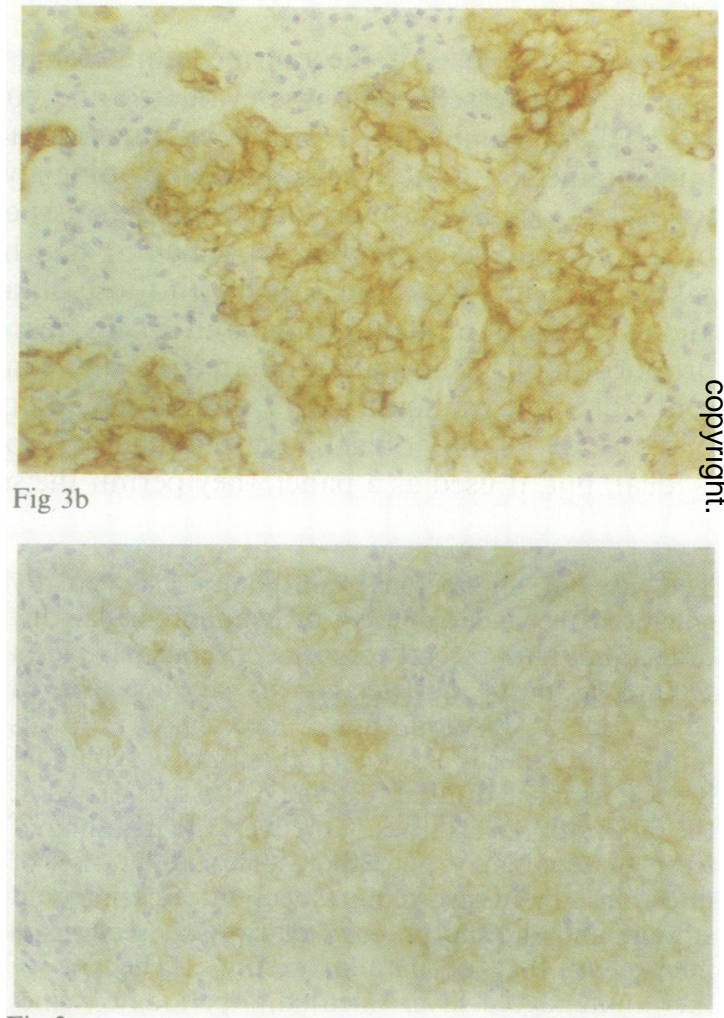

Fig $3 c$

Fig 3 (a) Nasopharyngeal carcinoma (haematoxylin and eosin) stained with (b) CAM 5.2, an antibody to low molecular weight cytokeratin. (c) Weak MB2 immuunostaining is present in neoplastic epithelial cells.

tions cut. Tissue obtained from routine tonsillectomies was snap frozen in isopentane and stored in liquid nitrogen until required when $6 \mu \mathrm{m}$ cryostat sections were cut and air dried before staining.

All paraffin sections were stained using the indirect 


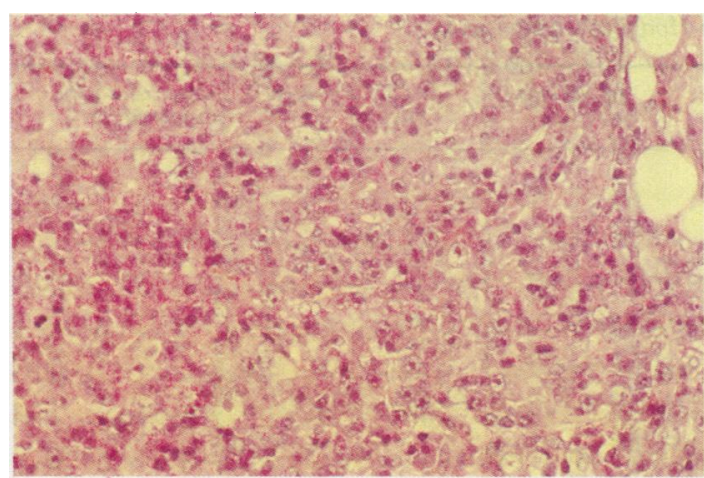

Fig 4a

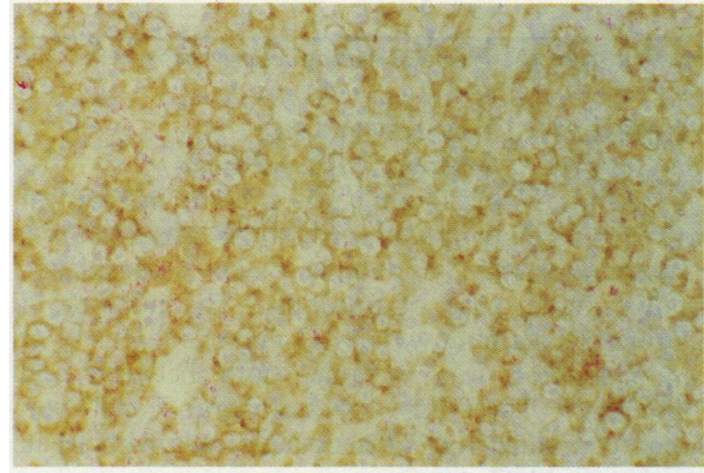

Fig 4b

Fig 4 Immunoblastic lymphoma (a) haematoxylin and eosin) showing strong MB2 cytoplasmic immunoreactivity, (b) indicating $B$ lineage. This was independently confirmed by cryostat immunophenotype studies.

immunoperoxidase method ${ }^{16}$ with overnight incubation of primary antisera at their optimal dilutions (MB2, 1/25; UCHL1 1/10; MB1 1/100; and MT1 1/5). Enzyme digestion was not required. Cryostat tonsil sections were incubated for 30 minutes with neat MB2.

All cases of non-Hodgkin's lymphoma were classified according to the Kiel classification. Except for $\mathrm{T}$ lymphocytic lymphoma, mycosis fungoides, and $\mathrm{T}$ immunoblastic lymphoma, peripheral $\mathrm{T}$ cell lymphomas were not further divided. Sixty four cases of non-Hodgkin's lymphoma were immunostained with MB2 and UCHL1 and the results of cryostat or cell suspension phenotype were available in $51(81 \%)$ of these cases. Twenty seven selected cases were additionally stained with MB1 and MT1.

\section{Results}

NORMAL AND REACTIVE LYMPHORETICULAR TISSUES

In cryostat and paraffin sections MB2 stained
Table 1 Non-lymphoid tissues exhibiting $M B 2$ immunoreactivity

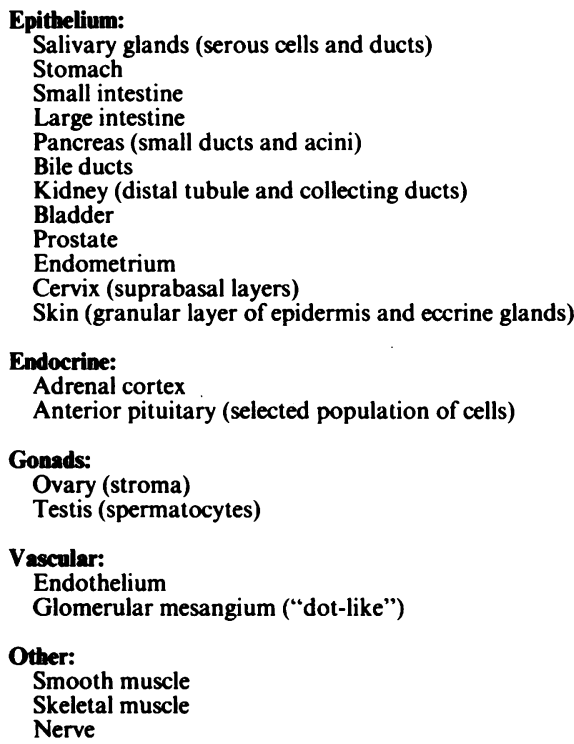

Table 2 Reactivity of MB2 with non-lymphoid neoplasms

\begin{tabular}{lll}
\hline & $\begin{array}{l}\text { No of cases } \\
\text { examined }\end{array}$ & MB2 \\
\hline Adenoma of: & 1 & + \\
$\quad$ Rectum & 2 & + \\
$\quad$ Leiomyroid & 1 & + \\
Meningioma & 1 & + \\
Adenocarcinoma of: & 2 & + \\
$\quad$ Rectum & 2 & + \\
Stomach & 2 & + \\
Pancreas & 2 & + \\
Breast & 2 & + focal \\
$\quad$ Pidney & 2 & + \\
Prastate & 2 & + \\
Nasopharyngeal carcinoma & 1 & + \\
Squamous carcinoma of: & 1 & + \\
$\quad$ Skin & 2 & + \\
Cervix & 1 & + \\
Melanoma & 2 & + \\
Oat cell carcinoma & 2 & - \\
Medullary carcinoma of thyroid & 1 & - \\
Secondary carcinoma of marrow & 2 & + \\
Pleomorphic adenoma & 1 & + focal \\
Phaeochromocytoma & 1 & - \\
Thymoma & 1 & + \\
Neuroblastoma & 1 & - \\
Ewing's sarcoma & 1 & - \\
\hline
\end{tabular}

strongly the cytoplasm of mantle zone cells and most germinal centre B cells, although less intensely (fig 1). Marginal zone lymphocytes in spleen were similarly positive. There was also staining of some lymphocytes in the interfollicular areas of all normal lymphoid tis- 
Table 3 Results of immunostaining with $M B 2$ and UCHL1 in non-Hodgkin's lymphomas

\begin{tabular}{|c|c|c|c|c|c|}
\hline Kiel subtype & Lineage & No of cases & $\begin{array}{l}\text { MB2 positive } \\
\text { cases }\end{array}$ & $\begin{array}{l}\text { UCHLI positive } \\
\text { cases }\end{array}$ & $\begin{array}{l}\text { No of cases with } \\
\text { phenotype }\end{array}$ \\
\hline $\begin{array}{l}\text { Lymphocytic } \\
\text { Hairy cell leukaemia } \\
\text { Lymphoplasmacytoid } \\
\text { Centroblastic/centrocytic } \\
\text { Centrocytic } \\
\text { Centroblastic } \\
\text { Immunoblastic } \\
\text { Burkitt's lymphoma } \\
\text { Lymphoblastic } \\
\text { Mycosis fungoides } \\
\text { Peripheral T cell } \\
\text { Unclassified } \\
\text { Myeloma }\end{array}$ & $\begin{array}{l}\mathbf{B} \\
\mathbf{T} \\
\mathbf{B} \\
\mathbf{B} \\
\mathbf{B} \\
\mathbf{B} \\
\mathbf{B} \\
\mathbf{B} \\
\mathbf{T} \\
\mathbf{B} \\
\mathbf{B} \\
\mathbf{T} \\
\mathbf{T} \\
\mathbf{T} \\
? \\
\mathbf{B}\end{array}$ & $\begin{array}{r}5 \\
1 \\
2 \\
8 \\
8 \\
3 \\
9 \\
4 \\
3 \\
2 \\
2 \\
3 \\
2 \\
10 \\
1 \\
1\end{array}$ & $\begin{array}{l}5 \\
0 \\
2 \\
8 \\
8 \\
3 \\
8 \\
2 \\
0 \\
2 \\
2 \\
0 \\
0 \\
3 \ddagger \\
0 \\
0\end{array}$ & $\begin{array}{l}0 \\
1 \\
0 \\
0 \\
0 \\
0 \\
0^{*} \\
0+ \\
2 \\
0 \\
0 \\
2 \\
2 \\
9 \\
0 \\
0\end{array}$ & $\begin{array}{l}4 \\
1 \\
2 \\
7 \\
7 \\
3 \\
7 \\
3 \\
2 \\
2 \\
2 \\
2 \\
1 \\
7 \\
0 \\
0\end{array}$ \\
\hline
\end{tabular}

*Three of nine cases gave cytoplasmic staining; tone of four cases gave cytoplasmic staining; $\ddagger$ weak focal staining in some tumour cells.

sue. In the thymus cells of the cortex were not stained by MB2, but some cells in the medulla were MB2 positive. In addition, MB2 gave weak cytoplasmic staining in Hassell's corpuscles. Plasma cells, tingible body macrophages, follicular dendritic reticulum cells, interdigitating reticulum cells and granulocytes were all negative, as were sarcoid granulomata in one reactive node. In contrast to $\mathrm{MB} 2$, the monoclonal antibodies UCHL1, MB1, and MT1 all produced membrane rather than cytoplasmic staining of lymphocytes. UCHL1 and MT1 reacted with lymphocytes in $\mathrm{T}$ cell areas of normal lymphoid tissues, and MB1 reacted with lymphocytes in B cell areas. Staining with MB1 was, in general, weaker than with MB2, and, like MB2, immunoreactivity was weakest with germinal centre cells.

\section{NORMAL AND NEOPLASTIC NON-LYMPHOID}

TISSUE (TABLES 1 AND 2)

Cytoplasmic MB2 immunoreactivity was found extensively in non-lymphoid tissues. In particular, there was widespread staining of normal and neoplastic epithelia (figs 2 and 3). This was usually weak but of differential intensity in different sites-for example, pancreatic acini showed weak MB2 staining, while small ducts showed strong cytoplasmic staining. The large ducts were negative, except for weak luminal margin staining. Islets were not stained.

UCHL1 also showed weak staining of cytoplasm of numerous non-lymphoid tissues, including the epithelium of gut, breast, pancreas, urinary tract, endometrium, squamous epithelium, salivary ducts, hepatocytes, smooth muscle and trophoblast. Weak cytoplasmic immunostaining with UCHLl was also seen in a leiomyoma, four gastrointestinal carcinomas, and two pancreatic carcinomas. Reactivity of MB1 and MT1 with non-lymphoid tissues was not systematically investigated.

\section{LYMPHORETICULAR NEOPLASMS}

Non-Hodgkin's lymphoma (tables 3 and 4)

Cytoplasmic MB2 staining was present in forty of forty four B cell lymphomas (fig 4) but absent in two B immunoblastic lymphomas, one centroblastic tumour, and a case of myeloma. The number of tumour cells staining with MB2 and the intensity of immunostaining was variable, both between and within cases. Three cases of peripheral $\mathrm{T}$ cell lymo phoma contained foci of neoplastic cells with weak cytoplasmic MB2 staining.

Table 4 Results of staining in tumour cells in selected cases examined with MB2, MB1, UCHL1 and MT1

\begin{tabular}{|c|c|c|c|c|c|}
\hline \multicolumn{2}{|l|}{ Kiel subtype } & $M B 2$ & $M B 1$ & UCHLI & \multirow{2}{*}{$\begin{array}{l}M T 1 \\
0\end{array}$} \\
\hline Lymphocytic & $\begin{array}{l}\mathrm{B}^{*} \\
\mathrm{~T}^{*}\end{array}$ & $\begin{array}{l}2 \\
0\end{array}$ & $\begin{array}{l}0 \\
0\end{array}$ & $\begin{array}{l}0 \\
2\end{array}$ & \\
\hline Hairy cell leukaemia & $\mathbf{B}^{*}$ & 2 & 2 & 0 & 0 \\
\hline Lymphoplasmacytoid & $\begin{array}{l}\mathbf{B}^{*} \\
\mathbf{B}^{*} \\
\mathbf{B}^{*}\end{array}$ & $\begin{array}{l}3 \\
3 \\
2\end{array}$ & $\begin{array}{l}0 \\
1 \\
2\end{array}$ & $\begin{array}{l}0 \\
0 \\
0\end{array}$ & $\begin{array}{l}0 \\
0 \\
0\end{array}$ \\
\hline \multicolumn{6}{|l|}{ Centroblastic/ } \\
\hline centrocytic & $\begin{array}{l}\mathbf{B}^{*} \\
\mathbf{B}^{*} \\
\mathbf{B}^{*}\end{array}$ & $\begin{array}{l}2 \\
2 \\
2\end{array}$ & $\begin{array}{l}2 \\
2 \\
2\end{array}$ & $\begin{array}{l}0 \\
0 \\
0\end{array}$ & $\begin{array}{l}0 \\
0 \\
0\end{array}$ \\
\hline Centrocytic & B $^{*}$ & 2 & 2 & 0 & 0 \\
\hline \multirow[t]{3}{*}{ Centroblastic } & $\begin{array}{l}\mathbf{B}^{*} \\
\mathbf{B}^{*}\end{array}$ & $\begin{array}{l}3 \\
2\end{array}$ & 2 & $\begin{array}{l}0 \\
0\end{array}$ & $\begin{array}{l}0 \\
0\end{array}$ \\
\hline & $\mathbf{B}^{*}$ & 0 & 0 & $0+$ & 0 \\
\hline & $\mathbf{B}^{*}$ & 1 & 0 & 0 & 0 \\
\hline \multirow[t]{2}{*}{ Immunoblastic } & $\mathbf{B}^{*}$ & 3 & 0 & 0 & 0 \\
\hline & $\begin{array}{l}\mathbf{B}^{*} \\
\mathbf{B}^{*}\end{array}$ & $\begin{array}{l}3 \\
0\end{array}$ & 2 & $\begin{array}{l}0 \\
0\end{array}$ & $\begin{array}{l}0 \\
0\end{array}$ \\
\hline \multirow{2}{*}{ Lymphoblastic } & B* $^{*}$ & 3 & 3 & 0 & 0 \\
\hline & $\mathrm{T}^{*}$ & 0 & 0 & $\mathbf{0}$ & 2 \\
\hline \multirow{5}{*}{$\begin{array}{l}\text { Mycosis fungoides } \\
\text { Peripheral T cell }\end{array}$} & $\mathbf{T}$ & 0 & $\mathbf{0}$ & 3 & 3 \\
\hline & $\mathrm{T}^{*}$ & 0 & 0 & 3 & 3 \\
\hline & $\mathrm{T}^{*}$ & $\begin{array}{l}0 \\
0\end{array}$ & $\begin{array}{l}0 \\
0\end{array}$ & $\begin{array}{l}3 \\
3\end{array}$ & $\begin{array}{l}3 \\
2\end{array}$ \\
\hline & $T$ & 0 & $\begin{array}{l}0 \\
0\end{array}$ & $\begin{array}{l}3 \\
0\end{array}$ & 0 \\
\hline & $\mathbf{T}$ & 1 & 1 & 2 & 2 \\
\hline Unclassified & ? & $\mathbf{0}$ & $\mathbf{0}$ & 0 & 0 \\
\hline Myeloma & $\mathrm{B}^{*}$ & $\mathbf{0}$ & 0 & 0 & 0 \\
\hline
\end{tabular}

*Phenotype known; tcytoplasmic staining present; $0=$ no cells, $1=$ some cells, 2 = many cells, $3=$ all cells staining. 
Membrane staining with UCHL1 was not found in the neoplastic cells in any case of B cell lymphoma. Three of nine centroblastic and one of four Bimmunoblastic tumours, however, did exhibit cytoplasmic staining with this antibody. Scattered reactive cells were UCHL1 positive in most cases. Three of $19 \mathrm{~T}$ cell lymphomas failed to show any UCHL1 immunoreactivity (T lymphoblastic, $\mathrm{T}$ immunoblastic, peripheral $\mathrm{T}$ cell lymphoma). The 16 other cases showed strong membrane staining in most tumour cells.

Table 4 shows the results of immunostaining with MB1 and MT1 in 27 selected cases. Of the 18 B cell tumours, MB2 was negative in two and $\mathrm{MB1}$ was also not demonstrable in these cases. MB1 was negative in a further four cases and was weaker than MB2 in four cases. MB1 staining was stronger than MB2 in one case, a centroblastic lymphoma. With the exception of a case of $\mathrm{T}$ lymphoblastic lymphoma, where UCHL1 was negative and MT1 positive, the staining with UCHL1 and MT1 was comparable. A high grade unclassified lymphoma without phenotypic data was not stained with any marker, nor was a centroblastic tumour, nor one case of myeloma.

\section{Hodgkin's disease}

All four antibodies failed to react with SternbergReed cells in all 13 cases of Hodgkin's disease examined. These included the following subtypes: lymphocyte predominant $(n=3)$; nodular sclerosing $(\mathrm{n}=4)$; mixed cellularity $(\mathrm{n}=3)$; lymphocyte depleted $(n=3)$. In all cases the surrounding lymphocytes showed immunoreactivity with UCHLl and MT1, or MB1 and MB2, with varying proportions of each.

\section{Discussion}

The ability to show specific lymphoid subset antigens in conventionally fixed and processed sections would be of great value to the histopathologist and would lessen the need to obtain fresh tissue for phenotypic studies. Although a wide range of reagents are available for the recognition of lymphoid and accessory cell antigens in cryostat sections, ${ }^{2}$ at present few monoclonal antibodies can be applied to paraffin sections. ${ }^{8-14}$ To be of maximal value any new monoclonal antibody should be tested in a wide variety of tissues, and detailed biochemical and immunological characterisation of the antigen is required. We examined the immunoreactivity of MB2 and UCHL1 on a wide range of normal and neoplastic tissues and compared the staining given by MB1 and MT1 in selected cases.

Our results indicate that MB2 recognises a cytoplasmic antigen expressed in mantle zone, and less strongly in germinal centre cells. It is also present in a small proportion of cells in the interfollicular areas. It is not certain whether these interfollicular cells are of B cell or T cell lineage but it is known that the MB2 antigen may be weakly expressed on some $\mathrm{T}$ cells. ${ }^{17}$

MB2 immunoreactivity is widely distributed in non-lymphoid tissues and their neoplasms. Whether the antigen recognised here is the same as the $28 \mathrm{kD}$ antigen shown in B lymphocytes is not known. That the non-lymphoid tissue distribution is not a nonspecific phenomenon is indicated by the selective nature of immunostaining observed in some tissues such as kidney and pancreas. The observation of nonlymphoid staining is of practical importance: if a tumour is not initially confirmed as being lymphoidfor example, by the presence of leucocyte common antigen - then the presence of MB2 immunoreactivity may lead to erroneous conclusions.

The distribution of UCHL1 in normal and neoplastic tissues in our study confirms the findings of Norton et al. ${ }^{11}$ Weak cytoplasmic staining, however, was seen in cases of centroblastic and immunoblastic lymphoma, and hence we emphasise the importance of only accepting ring like membrane staining as evidence of $T$ cell lineage.

When used in parallel, MB2 and UCHL1 provide useful tools for the recognition of $B$ and $T$ lymphocytes in paraffin sections. Neither is, however, an ideal reagent, as MB2 is expressed weakly on $\mathrm{T}$ cells ${ }^{17}$ and UCHL1 is not found on all $\mathrm{T}$ cells. ${ }^{15}$ Rare $\mathrm{T}$ cell neoplasms are UCHLl negative, and thus the absence of staining does not exclude the possibility of a $\mathrm{T}$ cell phenotype. Similarly, occasional B cell tumours are MB2 negative, and a negative result therefore cannot exclude a B cell phenotype.

The results obtained with MB1 and MT1 are similar to those reported by others. ${ }^{1213}$ Both are membrane markers, with MB1 having a similar distribution in lymphoid tissues to MB2, and MT1 being similar to UCHL1. The distribution of MB1 and MB2, or MT1 and UCHL1 in lymphoid neoplasms is similar, although occasionally one marker may be more strongly expressed than the other. In particular, MB1 tended to be weaker than MB2. In some cases only one marker was positive on tumour cells-MT1 was positive on the cells of a case of T lymphoblastic lymphoma in which UCHL1 was negative. Rare cases failed to express any detectable marker despite being morphologically and immunohistochemically - that is, leucocyte common antigen positive - of lymphoid origin.

As MB1, MB2, MT1 and UCHL1 seem to recognise different antigens there are clear advantages in using all four reagents as a panel to assess the B cell or $T$ cell nature of lymphoid neoplasms. Although none of the reagents is ideal, they can, if used carefully, 
permit the separation of $B$ and $T$ cells in formalin fixed paraffin embedded sections.

\section{Addendum}

Since submission of this manuscript we have observed staining of Reed-Sternberg cells with MB2 in cases of lymphocyte predominant Hodgkin's disease of nodular subtype.

PA Hall is an ICRF Clinical Research Fellow and AJ d'Ardenne and AG Stansfeld are supported by the ICRF. We acknowledge the generosity of BioNuclear Services Ltd and EuroDiagnostic Ltd for supplying antibodies, and we are grateful to Dr P Beverley for the gift of UCHL1.

\section{References}

1 Warnke RA, Weiss LA. Practical approach to the immunodiagnosis of lymphomas emphasising differential diagnosis. Cancer Surveys 1985;4:349-58.

2 Stein H, Lennert K, Feller AC, Mason DY. Immunohistological analysis of human lymphoma: correlation of histological and immunological categories. Adv Cancer Res 1984;42:67-147.

3 Gatter KC, Falini B, Mason DY. The use of monoclonal antibodies in histopathological diagnosis. In: Anthony PP, MacSween NM, eds. Recent advances in histopathology. London: Churchill Livingstone, 1984:35-66.

4 Holgate CS, Jackson P, Cowen PN, Bird CC. Immunogold-silver staining: new method of immunostaining with enhanced sensitivity. J Histochem Cytochem 1983;31:938-44.

5 Collings LA, Poulter LW, Janossy G. The demonstration of cell surface antigens on $T$ cells, B cells and accesary cells in paraffin embedded human tissues. J Immunol Methods 1984;75:227-40.

6 Brenes F, Harris S, Paz M, Petrovic LM, Scheur PJ. PLP fixation for combined routine histology and immunocytochemistry of liver biopsies. J Clin Pathol 1986;39:459-63.
7 Stein H, Gatter KC, Asbahr H, Mason DY. Use of freeze dried paraffin embedded sections for immunohistological staining with monoclonal antibodies. Lab Invest 1985;52:676-83.

8 Warnke RA, Gatter KC, Falini B, et al. Diagnosis of human lymphoma with monoclonal anti-leucocyte antibodies. New Engl J Med 1983;309:1275-81.

9 Epstein AL, Marder RJ, Winter JN, Fox RI. Two new monoclonal antibodies ( $\mathrm{LN}-1, \mathrm{LN}-2)$ reactive in $\mathrm{B} 5$ formalin fixed, paraffin embedded tissues with follicular centre and mantle zone human B lymphocytes and derived tumours. $J$ Immunol 1984;133:108-36.

10 Marder RJ, Variakojis D, Silver J, Epstein AL. Immunohistochemical analysis of human lymphomas with monoclonal antibodies to B cell and Ia antigens reactive in paraffin sections. Lab Invest 1985;52:497-504.

11 Norton AJ, Ramsay AD, Smith SH, Beverley PCL, Isaacson PG Monoclonal antibody (UCHL1) that recognises normal and neoplastic $T$ cells in routinely fixed tissues. J Clin Patho 1986;39:399-405.

12 West KP, Warford A, Fray L, Allen M, Campbell AC, Lauder I. The demonstration of $B$ cell, $T$ cell and myeloid antigens in paraffin sections. J Pathol 1986;150:89-102.

13 Dobson CM, Krajewski AJ, Myskow MW, Horne CHW. Value of $\mathrm{MB} 1$ and $\mathrm{MT} 1$ monoclonal antibodies in lymphoma diagnosis. J Pathol 1986;148:81 A.

14 Norton AJ, Isaacson PG. Granulocyte and HLA-D region specific monoclonal antibodies in the diagnosis of Hodgkin's disease. J Clin Pathol 1985;38:1241-6.

15 Smith SH, Brown HM, Rowe D, Callards RE, Beverley PCL. Functional subsets of human helper-inducer cells defined by a new monoclonal antibody UCHL1. Immunology 1986; 58:63-70.

16 Van Noorden S, Polak JM. Immunocytochemistry today Techniques and Practice. In: Polak JM, van Noorden S, edsImmunocytochemistry. Practical applications in pathology ani biology. Bristol: Wright PSG, 1983:11-42.

17 Poppema S, Hollema H, Visser L, Vos H. Monoclonal antibodies (MT1, MT2, MB1, MB2, MB3) reactive with leukocyte subsets in paraffin embedded tissue sections. Am J Pathol (in press).

Requests for reprints to: Dr PA Hall, ICRF Research Fellow, Department of Histopathology, St Bartholomew's Hospital, London EC1A 7BE. 